\title{
Design of a small and medium industry cluster in cilegon city with supply chain system approach
}

\author{
Dyah Lintang Trenggonowati ${ }^{1,{ }^{*}}$, Asep Ridwan ${ }^{2}$, and Zunika Dwi Anggraini ${ }^{3}$ \\ ${ }^{1,2,3}$ Engineering Department Faculty of Engineering, University of Sultan Ageng Tirtayasa, Banten
}

\begin{abstract}
Future industrial development strategies, derived from current ideas, that is industrial development through a cluster approach. Cilegon city is a city with many petrochemical industries and other, it should be a potential that can give a positive impact for the welfare of Cilegon city community, the researchers want to design the cluster of the petrochemical derivative of IKM with supply chain system approach. The objective of the research is to design the development of a petrochemical derivative cluster of IKM in Cilegon, to determine the factors that influence the development of SMEs clusters, and to design improvement scenarios in the development of SMEs clusters with dynamic system simulations. Based on the results of SMEs cluster design, the stakeholders in the design are government, big companies, and business actors. Types of products to be produced are plastic packaging, plastic bottles, and plastic bags. The location of the right cluster of IKM development is located in Grogol sub-district. Raw materials used by petrochemical derivatives can be obtained from factories producing polyethylene in Grogol sub-district such as PT Lotte Chemical Titan. Factors that have the significant effect on SMEs cluster development are the factors of government support and local business power factor. The simulation result shows that the second alternative proposal is considered reliable enough to face the fluctuating market demand. From the simulation results obtained the average production of $228,513,6914 \mathrm{psc}$, the average production stock $821,742.4$ and the average sales of 200,000 psc. $\square$
\end{abstract}

\section{Preliminary}

The era of globalization today has brought about a very rapid renewal and a major impact on the economy both at home and abroad. The impact is most felt is increasingly fierce competition globally in the industrial sector. The industrial sector is a major sector in national economic development. The industrial sector in Indonesia in of global competition cannot be released from the strategy implemented. The strategy of the industrial development in the future, adapting to the ideas developed at the moment, namely the development of the industry through the cluster approach. According to Sa id in Nusantoro (2011) it clear that clusters are the relationship between one type of economic activity, start

*Corresponding author: dyahlintang@untirta.ac.id 
from the activities of the production of primary, collectors, processing products and a half or the finished product. According to Chopra (2007), The benefits that can be obtained in general is to promote the specialization of production in accordance with the competencies of the core and encourage the transformation of a comparative advantage to be a competitive advantage. The competitive cannot be separated from the supply chain the manufacture of products from upstream to downstream. Ridwan (2017) said that the supply chain is a system in the organization that transfers goods production and services to its customers. Cilegon city which is in the western tip of Java island is a city that is taken by the main trade of goods and services from Java to Sumatra Island and otherwise. The location of Cilegon, which is very strategic and supported by the existence of those industries with large capital intensive which is in the Cilegon city, and surrounding areas, should be the potential for being, and it's got to be able to provide a positive impact for the welfare of the city of Cilegon. Based on the condition it is in this study researchers want to do research on the establishment and development of clusters IKM in the city of Cilegon, with the supply chain approach, especially in the petrochemical industry as well as analyze what factors affect the development of clusters of industry and downstream petrochemicals with that of the Partial Least Square. The research also aims to provide a recommendation that can optimize the development of clusters with dynamic systems simulation method.

\section{Methodology}

The purpose of the use of PLS is to do the relationship between construct. In contrast to PLS which aims to make predictions, the use of SEM is intended as a method to confirm the theory, so that it can be said that PLS is more oriented to the prediction and SEM to be on the theory. The excess of PLS, according to Abdillah and Jogiyanto (2009) is:

1. Being able to model a lot of variables dependent and variable independent.

2. Being able to manage the problem of multicollinearity between variables are independent.
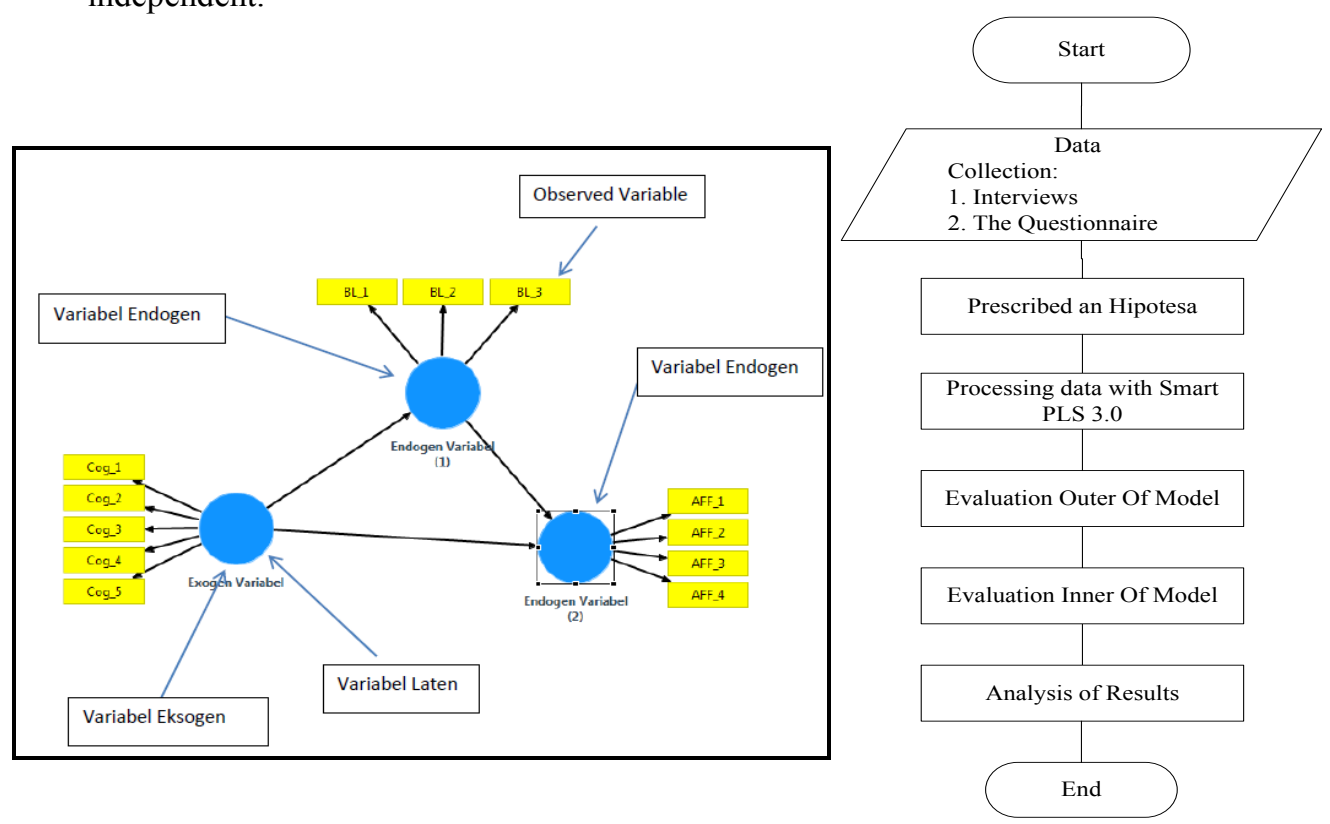

Fig. 1. Conceptual Model of PLS Method and Flow Chart Analysis Of Factors Using Methods PLS. 
3. The result remains strong even though there is the data that is not normal and goes.

4. Making a variable is latent independent directly based on cross-product that involves variables latent dependent as the predictions.

5. Can be used in constructed reflective and formative.

6. Can be used in the tiny sample.

7. It requires data distribution.

8. Can be used in the data to the type of scale.

From Fig. 1. above can be seen that there are several reasons that cause used PLS in a research. In this study the reasons, namely: first, PLS is a method of analysis of data based on the samples don't have to be big, which is the number of samples less than 100 can do the analysis. Second, PLS can be used to analyze the theory still said to be weak, because PLS can be used for predictions. Third, PLS allow the algorithms by using analysis of the series Ordinary Least Square (OLS) to achieve the efficiency of the logarithm.Fourth, on the approach PLS, it is assumed that all variance can be used to explain. Here is a flowchart analysis of factors using the method of PLS.

\section{Model development}

\subsection{Design Of Clusters IKM a Descent Petrochemical of Cilegon City}

Here is the design of cluster IKM a descent petrochemical of Cilegon city :

1. Stakeholder

The development of clusters IKM needs cooperation between the actors involved. Stakeholder a role in the development of clusters IKM is the government, the company, and business leaders.

2. Type of Product

Products that can be produced by clusters of IKM the petrochemical Cilegon, among others, are plastic packaging, plastic bottles, and a plastic bag.

3. The Location Cluster IKM of Plastic of Cilegon

Seen from a lot of companies petrochemicals that are around the district Grogol.

4. The Need For Market

The need for plastic in Indonesia increasingly, it can be seen from a statement from the Minister of Industry (Menperin) who said that "The plastic products to 4, 6 million tonnes and increased by five percent in the last five years".

5. The availability of Raw Material

The source of raw materials is the most important factor in the selection of the clusters IKM, especially on cluster IKM the raw materials. The raw material of plastic is polyethylene. The raw material can be obtained from plants that produce polyethylene in the district Grogol like PT Lotte Chemical Titan, and could also be from the company around like PT Chandra Asri.

6. The Transportation Facilities

The Klaster IKM of plastic, they would build in the district Grogol, Cilegon, close to the factory that produces raw materials for polyethylene., Grogol also close to the facilities and infrastructure of transportation such as toll roads Jakarta-Merak, the airport in, means of transport by train, as well as the port. This will provide facilities for the delivery of the product, operational and administrative management of the management cluster IKM. 
7. The Government Policy

In accordance with the policy of the development of industry, The government has decided the area of Cilegon, as the industry that is open to foreign investors. the Government as facilitator has provided facilities for licensing, taxes and other things related to the technical implementation of the creation of a factory.

\subsection{Testing conceptual model}

\subsubsection{Convergent Validity}

Convergent validity aims to measure compatibility between indicators of measurement variables and the theory that explains existence as an indicator of the test of these variables. The convergent validity can be evaluated in two stages is to look at the outer loadings and a height of variance extracted (AVE).

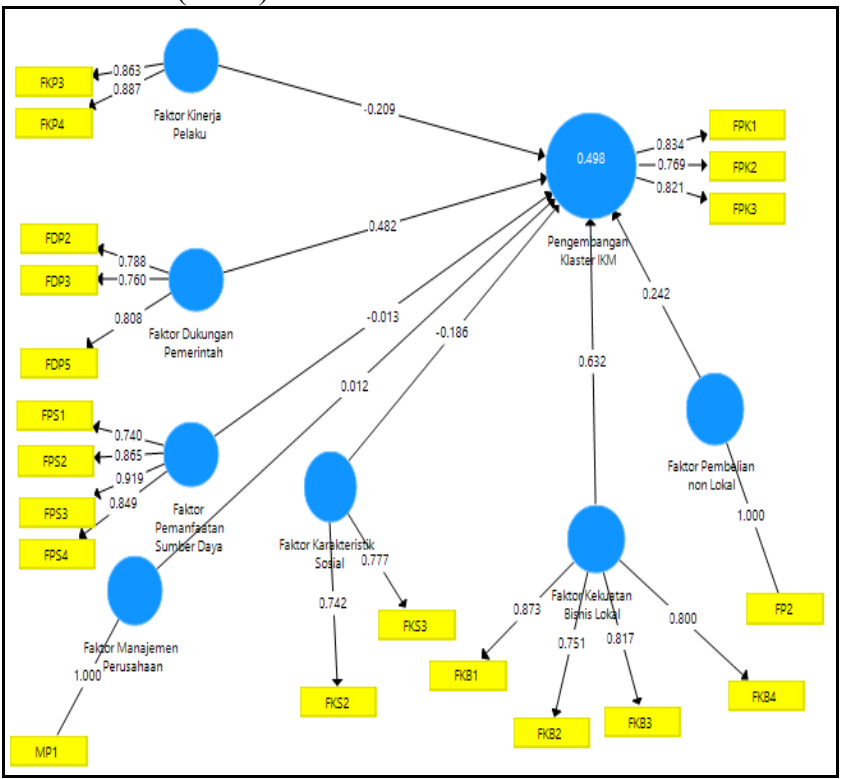

Fig. 2. Diagram of re-estimate line

From the Fig. 2. Can be seen that the outer loading must be greater than 0,7 it is said to be valid. From Fig. 2 the results of calculations Algorithm Report Smart PLS still there is the outer loading under 0.7 For it's done re-estimate to eliminate indicators, which is under 0.7 .

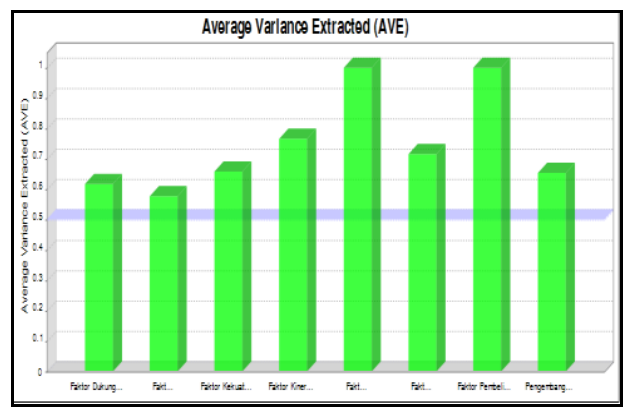

Fig. 3. Graph of AVE 
The next step is to look at the AVE. The AVE aims to measure the level of variance a construct component to figures compiled from the indicators by adjusting the error rate. The AVE a minimum recommended is 0, 50. Output AVE can be seen in the picture below. From the Fig. 3. above can be seen that output AVE the respective variables latent is greater than 0,5 it shows that each of these variables latent was said to be valid.

\subsubsection{Discriminant Validity}

Discriminant validity is the level of the difference an indicator of measuring constructs the instrument. The assessment discriminant validity is generated by Smart PLS and discussed in this study the Fornell-Lacker Criterion and cross the loading. The following is the result of the cross-loadings of PLS Algorithm Report Smart PLS. From Cross Loadings process is known that each construct indicator correlated are higher with constructing the association compared with constructed so it can be said to have discriminant validity. The next step in discriminant validity is to compare the correlation between variables with $\sqrt{ }$ AVE. The measurements have discriminant validity is a good thing if $\sqrt{ }$ AVE every variable is greater than the correlation between the variables. The $\sqrt{ }$ AVE was that for judging from the output Fornell-Lacker Criterion Smart PLS are presented in Table 1. below.

Table 1. Output fornell-lacker criterion

\begin{tabular}{lllllllll}
\hline & FDP & FKS & FKB & FKP & MP & FPS & FP & FPK \\
\hline FDP & $0,786^{*}$ & & & & & & & \\
FKS & 0,608 & $0,759^{*}$ & & & & & & \\
FKB & 0,326 & 0,610 & $0,811^{*}$ & & & & & \\
FKP & 0,263 & 0,343 & 0,600 & $0,875^{*}$ & & & & \\
MP & 0,136 & 0,194 & 0,325 & 0,201 & $1,000^{*}$ & & & \\
FPS & 0,209 & 0,367 & 0,694 & 0,628 & 0,113 & $0,846^{*}$ & & \\
FP & $-0,220$ & $-0,075$ & 0,175 & 0,345 & 0,167 & 0,161 & $1,000^{*}$ & \\
FPK & 0,465 & 0,400 & 0,586 & 0,310 & 0,243 & 0,366 & 0,188 & $0,809^{*}$ \\
\hline
\end{tabular}

From the results of each variable shows $\sqrt{ }$ AVE more than a correlation between variables, so that the terms discriminant validity with $\sqrt{ }$ AVE are met

\section{Result and Discussion}

There are significant differences between the system simulation existing a simulated improvement repairs 1 and improvement repairs, the after ANOVA with the use of the Least of all the Significant Differences (LSD) to know the average of the condition or treatment which different. Here is the result of the test after ANOVA using software SPSS.

Based on Table 2. the test results after ANOVA, known to the lower bound and the upper bound in every comparison of outputs that have not passed through, then rejected H0 which means there are significant differences between the average output system simulation existing with simulated improvement repairs.

Based on Table 3. the best condition is a model of the improvement of the 2 with an average of the product as much as 228513.6914 psc, the next is improvement repairs one of the product as much as 185577.6629 psc and the last one is existing the average product as much as 125025.1 psc. 
Table 2. The results of the test after ANOVA with software SPSS.

\begin{tabular}{|c|c|c|c|c|c|c|}
\hline \multicolumn{7}{|c|}{$\begin{array}{l}\text { Dependent Variable: Simulasi } \\
\text { LSD }\end{array}$} \\
\hline \multirow[t]{2}{*}{ (I) Kondisi } & \multirow[t]{2}{*}{ (J) Kondisi } & \multirow{2}{*}{$\begin{array}{c}\text { Mean } \\
\text { Difference }(I-J)\end{array}$} & \multirow[t]{2}{*}{ Std. Error } & \multirow[t]{2}{*}{ Sig. } & \multicolumn{2}{|c|}{ 95\% Confidence Interval } \\
\hline & & & & & Lower Bound & Upper Bound \\
\hline \multirow{2}{*}{1.00} & 2.00 & $-60552.57000^{\circ}$ & 15286.84713 & .001 & -92669.0441 & -28436.0959 \\
\hline & 3.00 & $-103488.59857^{\circ}$ & 15286.84713 & .000 & -135605.0726 & -71372.1245 \\
\hline \multirow{2}{*}{2.00} & 1.00 & $60552.57000^{\circ}$ & 15286.84713 & .001 & 28436.0959 & 92669.0441 \\
\hline & 3.00 & $-42936.02857^{\circ}$ & 15286.84713 & .012 & -75052.5026 & -10819.5545 \\
\hline \multirow{2}{*}{3.00} & 1.00 & $103488.59857^{\circ}$ & 15286.84713 & .000 & 71372.1245 & 135605.0726 \\
\hline & 2.00 & $42936.02857^{\circ}$ & 15286.84713 & .012 & 10819.5545 & 75052.5026 \\
\hline
\end{tabular}

Table 3. The sequence of the best

\begin{tabular}{ccc}
\hline No & Condition & Average of Output (Psc) \\
\hline 1 & Improvement Scenario 2 & 228513.6914 \\
2 & Improvement Scenario 1 & 185577.6629 \\
3 & Existing & 125025.1 \\
\hline
\end{tabular}

\section{Conclusion}

Based on the results of research then obtained by the following conclusion :

1. Based on the clusters IKM the industry downstream petrochemical and can be seen that stakeholders in designing are the government, big companies, and business leaders. This type of products that are produced is plastic packaging, plastic bottles, and plastic bags. The development of clusters IKM the derivatives industry downstream petrochemicals the right is to be in the district Grogol. The raw material used in making products IKM the chemical can be obtained from the factory that produces polyethylene in the district Grogol like PT Lotte Chemical Titan. The prevailing means of transportation available, which is the toll Jakarta-Merak, the airport in the train, as well as the port.

2. The factor that has a significant effect on the development of clusters IKM is a factor of government support and the power of local businesses.

3. Based on the results of the simulation found that the proposal the second alternative is considered to be big enough to deal with market demand had been fluctuating in the proposed improvements in the changes in the structure of the decision is made of stock that is not static, but follows the average of sales. From the simulation then earned an average of $228.513 .6914 \mathrm{psc}$, the average stock production $821.742,4$ and the average sales of $200,000 \mathrm{psc}$.

\section{References}

1. Abdillah, W. dan Jogiyanto, H. M. Konsep Dan Aplikasi PLS (Partial Least Square) Untuk Penelitian Empiris. Badan Penerbit Fakultas Ekonomi Dan Bisnis UGM, Yogyakarta (2009) 
2. Chopra, S., \& Meindl, P, Supply Chain Management. New Jersey: Pearson Prentice Hall (2007)

3. Nusantoro, J. Model Pengembangan Produk Unggulan Daerah Melalui Pendekatan Klaster Di Provinsi Lampung (2011)

4. Ridwan A., Kulsum, Murni S., Pengukuran Dasar Kinerja Aliran Rantai Pasok dengan Pendekatan Metode Lean Six Sigma Supply Chain Management, Jurnal Teknik Industri Universitas Sultan Ageng Tirtayasa, Cilegon. Vol. 3 No. 1a (2017)

5. Ridwan A., Trenggonowati D.L., Haryanto H., Kustiningsih I., Sulaiman F., Masterplan Pengembangan Sentra Industri Kecil dan Menengah Kota Cilegon. Kerjasama COE dan BAPPEDA, Cilegon (2017) 